\title{
DISCOVERING THE MEANING OF THE NARRATIVE THERAPY IN THE CARITATIVE SOCIAL WORK CONTEXT
}

\author{
Guntis Dišlers \\ Latvian Christian Academy
}

\begin{abstract}
The method of the Narrative therapy originated at the end of the 20th century as an interdisciplinary practice and research between psychotherapy and social work. Caritative social work is aimed at more penetrating analysis of the clients' personality issues along with social issues involved in the crisis, and Narrative therapy is one of the ways to deal with it. The article presents the context of NT, the meaning of both dominating and alternative narratives. The practical application of the method is overviewed: externalization by which the client is separated from his problem along with identification of the critical points, the change of the viewpoint and position of the therapist. Narrative therapy may be used in work with individual clients, couples and families, also work with larger groups is possible. In the practice of caritative social work NT invites to refocus several aspects of the human identity perception.

KEY WORDS: client, narrative, therapy, dominating narrative, identity alternative, critical points, externalization.
\end{abstract}

\begin{abstract}
Anotacija
Naratyvinès terapijos, kaip tarpdisciplininio metodo, socialiniame darbe ir psichoterapijoje ištakos glūdi XX a. pradžioje. Jis svarbus karitatyviniame socialiniame darbe, kai siekiama padèti žmogui ištikus krizei, sprendžiant asmenybès ir socialines problemas. Straipsnyje pristatomas naratyvinès terapijos kontekstas, išryškinant dominuojantị ir alternatyvų naratyvus. Praktinis metodo pritaikymas aptariamas kompleksiškai atskleidžiant eksternalizacijos procesą, kurio metu klientas identifikuoja savo problemą, o terapeutas suvokia savo požiūrị. Naratyvinè terapija gali būti taikoma dirbant su individu, šeima, grupe. Karitatyvinio socialinio darbo praktikoje šis metodas igalina geriau suvokti asmens tapatumo klausimus.

PAGRINDINIAI ŽODŽIAI: klientas, terapija, dominuojantis naratyvas, tapatumo pokyčiai, kritiniai taškai, eksternalizacija.
\end{abstract}

DOI: http://dx.doi.org/10.15181/tbb.v79i3.1892

\section{Introduction}

The aim of the present article to re-introduce the content and key issues of the Narrative therapy to social workers. Brief overview of the key notions and methodological challenges of the NT in caritative social work practice are presented. Narrative therapy is to voice non-condemning and respectful attitude to the client mainly in individual setting. Founders of NT are well known for saying that a person is the best expert of his / her life. Following the general recognition, the main task during the therapy process is to separate between a person and his problems, 
since the person himself possesses all the necessary skills and competencies as well as values and abilities to reduce the impact of a problem on his life (White, Epston, 1990, p. 231). Both individual clients, couples and families may benefit from NT as long as they are subjects who define themselves by their problems and whose dominant feelings may be described as "I am depressed, preoccupied with my problems, I am looser, deep in my crisis", etc. Narrative therapy invites to see the problem as something the client "possesses" rather than "is identified" with it.

NT originated at the end 1960-ies, it was further developed during 70 -ies and 80 -ies. First authors who gave its theoretical framework was social worker from Australia Michael White and David Epston from New Zealand. NT may be seen as a form of psychotherapy when it deals with the way how people identify their values in confrontation with their life problems and challenges, and it takes us into the social work territory. White and Epston emphasized the motif of social justice in therapeutic conversation, since the so-called dominating narrative shows strong tendency towards overwhelming and subsequently all-encompassing and even destructive impact on individuals' self-perception. Consequently, NT challenges self-identification and self-determination of a person in a situation when the dominating narrative works as a destructive force. Narrative therapy experts speak about the inner conviction, about inner conflicts and resources to overcome them, about the motivation to act on a long-term basis due to existence of the so-called alternative narrative.

It is a recognized fact that people often take some narrative from outside as their own, creating dominating narrative to follow. It can happen for several reasons: due to some pressure, e.g., in ideologically authoritarian system the dominating narrative can be projected as repressive and individuals are forced to submit to their pressure, to "swallow" their inner opinion and to suppress own personal story (narrative) as invalid. After all, a person is a societal being and not everything he does follow his inner, personal conviction - rather they are tasks and responsibilities one should take in relationships with the state and its policy, and on more private level with family members, parents, colleagues, friends, etc. These surrounding narratives could be imagined as concentric rings since every person lives within many and diverse contexts.

The author holds NT sessions at Latvian Christian Academy together with social work specialists. They were invited to reflect on their clients' critical issues by presenting their narratives in a roll play; narratives were consequently discussed, questioned and analyzed. Participants were both males and females, age 35-50; work experience $5-10$ years. Best credibility of results and provision of success requires repeated reflection, return to the first encounter with the client and his original narrative, subsequent professional analysis, which is a time-consuming 
process asking for open communication and immediate feedback, and evaluation of results is expected from both therapist and a client. Participants of the training sessions were invited for repeated action and more penetrating analysis of some aspects (e.g., more purposeful search for causes of the crisis situation, personality identity issues related to future prospects etc.).

\section{Key notions}

\section{Client}

In what way the NT client differs from any other client in the social worker's office? First, he is ready to tell openly about himself. The word "narrative" means to "tell a story", naturally, this is the first requirement. Consequently, the NT can't be applied in work with everyone. The send requirement is certain amount of humility and readiness to voice some doubts regarding previous ways. However, in real life there are clients who are deeply convicted of their absolute truth and righteousness, they voice it without reserve and use both rational and emotional arguments to leave an impression. These clients may be called "self-righteous" if they address therapist only because they want to manifest triumph of their conviction and assurance of their own righteousness. Perhaps these clients don't fit the stage.

NT specialists emphasize that stories people tell about themselves and stories told about them by others contain essential information about their identity. Also, these stories contain essentially important hint at what they are capable of. The process of NT - firstly, listening to the client's story, enables to identify which values are important for the client and how he or she understands own personal skills and knowledge necessary for their implementation (Brown, Augusta-Scott, 2007, p. 36).

It is testified that a person in crisis is focused on himself more than on others (although sharp critique of "life circumstances" may be pronounced). Clients often doubt and even contradict themselves, often claim themselves losers or quite opposite - experiences euphoria and feel ready to start new life on different foundations. To put it differently, the NT client seems to be willing to "speak from his / her heart", to reveal everything what has been hidden and was unheard by others until now. However, being ready to speak out is not the same as being ready to act. A client may be more realistic - more cautious, thoughtful, questioning, willing to think over what he hears from the therapist before taking further insightful steps and decisions for further activities.

Decision making is a cognitive process when the subject accepts one of the provided alternatives. Mechanism of the decision making is not our topic here, it 
is described elsewhere in special literature (e.g., Kahneman, Amos, 2000; Triantaphyllou, 2000, etc.).

\section{Narrative}

Narrative (from Latin "message, story") in its simplest form is a story about an event, real or imagined, with more or less completed plot with its beginning, development until culmination and completion (outcome, result). The root of the Latin word is gnarus, meaning "knowledge" or "skill", consequently, narrative is conscious and willful act, informing about the condition of the teller, his values, worldview, convictions, etc. To translate this into the language of NT narrative is a story composed by the client and it deals with some particular life events he is willing to reveal to the therapist. In this sense everyone shares his narrative with his mates, friends, colleagues, etc. It should be underlined that the specific use of the narrative in therapy requires conscious search for causes of the crisis in the clients' life and is made of causes-and-consequences presented in a story".

Various narratives are crossing human consciousness (see Fig. 1); therefore, it is right to say that people live through several narratives simultaneously. Narrative is made of interrelated chains of regularities accepted as a life "baseline".

The way how people explain their behavior is influenced by both their inner convictions and some wider narratives, e.g., family, where we agree on something, relationships between father and mother, upbringing etc. Some influence lives positively as encouragements, whereas others work as motivators of destructive forces - consequently, narratives happen to interact in dynamic and even competing relationships. In similar circumstances people act differently, e.g., they can decide to step back against the superpower or to fight against although they know it brings disaster and even death.

Obviously, narrative is not "just a story to tell", since it leads to subjectively motivated behavior. Narratives illustrate how people conceptualize their past, present and shape their future. For example, Anita sees herself as skillful counselor, she is the author of the narrative which presents her as successful professional and it is supported by references from clients. It strengthens her conviction as being competent, emphatic and skillful. Most probably when being up to move to some other and less known job, Anita will think about herself in previously made terms, i.e., that her former qualification will pave good future with confidence.

How narratives are created?

For the therapist any narrative consists of four elements:

- separate events;

- sequence of elements; 
- narrative develops in time (separate elements may get improvement or, vice versa, loose importance);

- events are organized as plots (interactions between acting persons).

One of the key principles of NT is that reality as such is inaccessible, the philosophical concept that people touch only interpretation of reality. Narrative is just another "version of reality" and may be reflected through countless different interpretations. It is typical for people to interpret. Narratives function as connecting links between events in timeline, and people ascribe meaning to those chains. The narrative is an outward shell of the meaning and these meaningful chains lead to the next event, whereas every new event stems from the previous one. Thus, narrative is a thread which ties events together, creating a meaningful story. Human memory works in similar manner.

Everyone has many stories about personal life and relationships with other people, and these stories unfold simultaneously. Clients have stories about their skills, their struggles and wishes, about their relationships, interests, inner doubts and victories, and fails. Stories are made of diverse events tied together, and they are tinted with meaning. For example, Charles regretfully confesses that he's lost several years of his life working in a factory because "it was not my calling" and acquired skills have no application, therefore he feels depressed and envy those who do "what they like". Or - another story - George thinks he is very good driver, he observes traffic rules, cares for his car, shows good fellowship on the road, etc. However, he may think about himself "bad" following other criteria - he doesn't keep the speed limit when there is no-one to check it, his car actually doesn't match the use of it, he often drives tipsy and no-one has ever caught him, etc. Or he could be characterized as careless, even dangerous, if tiny mistakes are summed up, and he throws trash through the window, etc. Additionally, George spends all his free time in garage rather than relaxes together with his family, consequently his care for the car cause conflicts in family, etc. All these events contradict and evaluation of a person depends on narrative the observer puts in the first place.

Narratives can be simple and composite. Composite narratives are complicated both in their form and content, they comprise dominating and subordinate elements, they speak about several involved personalities. Complicated and composite narrative reminds textile with interwoven threads of various colors - although each one is clearly distinctive, it also leaves an impact on perception of others by contrast, transition of colors, etc. Similarly, any simple narrative could hardly be separated from others - since no life "belongs" only to a person discussed; in many ways it "belongs" also to others the client is related to in a family, work place, society at large etc. Exactly as an old saying goes: "One is not a warrior." 
However, clients are focused on some particular narrative, they overlook their past lives with a single question: "What was the chain of events that took me to crisis?" In this case the narrative formally reminds chain of events, whereas in essence it is a chain of causes and consequences, description of regularities.

For better perception of the narrative it is recommended to use an ecomap, a well-known drawing enabling to see the context of a client. Ecomaps show ties with other persons along with short characteristics of relationships. Well-made ecomap helps to separate essential information from the inessential, from unneeded turns in the plot, etc. Dominating narratives look more visible.

\section{Dominating narrative}

A person in his environment makes one living system of mutual turnaround. Narrative therapists pay attention to various contexts of any activity, and these contexts shape understanding of what is or is not "right" or "acceptable". Similarly, various narratives coexist and unfold - some of them cease whereas others increase due to various determinants. For description of the dynamics NT speaks about the so-called dominating narratives - they play crucially decisive role, since people show tendency to side with them consciously or subconsciously.

More than that - the environment influences the way how people ascribe meaning to their life events. For example, Anita's conviction that she is good therapist is shaped by the environment she's been into. The culture of environment supports specific perception of what is "skillful and good therapist", and Anita fully fits within this culture. However, after moving to another environment the match may (and most probably will) change and won't be that smooth. Or, skills of communication acquired in Latvia (or Lithuania) may be out of use in some foreign and remote country, etc. In those cases, narrative therapists speak about the impact of the dominant narrative. If tension between the subject and environment increases, therapists analyze compliance of the dominating narrative to circumstances and context of the environment.

On the other hand, various narratives compete - and the dominating one pushes less influential ones out and they become alternative. They may lose their importance or stay in periphery for the time being.

\section{Alternative narrative}

Narrative therapy sometimes is described as conversation which "dislocates the author" ("re-authoring") or "changes the story" ("re-storying") (Carey, Russell, 2003). Narratives in the given examples unfold simultaneously in different directions, in addition the same event can be reflected and described from various perspectives. There is no complex story without inner contradictions and no story 
is analyzed as isolated. If, for example, driver John has suffered in a car accident and there are other victims, he will fix his attention to all tiny details he admitted while driving. But he can also rethink all new traffic rules aimed at discipline of drivers like him. Similarly, interpretations by other people and witnesses along with the driver's explanations will make alternative stories about the John's driving style and role in the accident. Surely all alternative stories play some role in full understanding (i.e., meaning) of what happened. For some time a person may try to cope with different stories about the event coming from various sources (contexts, respondents), but sooner or later one particular narrative will take over and will increase its role, pushing others out.

Dominating narratives are created by both individuals and larger communities. For example, Latvians as "singing nation" is popular among outsiders, it works as an advertisement for tourists, whereas other narratives present Latvians as irritable and quarrelsome - these are insiders' narratives, not that flattering. Somewhat combination of both appears when journalists invite Latvians "to stay in unity as we were in the Song Festival", i.e., flattering narrative is preferred over the unpleasing one in social stress situation. Similarly, there may be a family narrative that tells its history and traditions, and there are narratives about relationships between the family members, and they leave and impact on future choices and relationships between the younger generation. For examples, the saying "we Johnsons do like this" confirms regulating function of the dominating narrative for proper behavior against the intolerable shift from the norm. Younger generation reacts sharply against conservatism and does everything possible against it - this is sure sign that an alternative narrative is in making. Or, for example, Dave may see himself as "loser without skills to manage something unknown", or, vice versa, he is "coward" and "hypocrite". None of these narratives is perspective, both of them are destructive, and they testify to omnipresence of the imposing dominating narrative. Therapist should penetrate into the history of making of them, especially when there is some alternative narrative hiding in the shadow of the dominating one.

A family can stick to the self-image of "caring for others", at the same time being "pretty noisy" and "risky" because it is "financially powerful". A community can stick to the narrative presenting it as "isolated" or "politically active" - all these narratives foresee stories which illustrate that image. Consequently, members of the community will find their meaning within this frame.

The life process requires maneuvering between dominating narratives on the one hand and alternative narratives on the other. People constantly "negotiate" between the both and they interpret their experience, they seek the golden middle between the external, dominating - often taken as uncongenial - and "our own" as personal alternative to the dominance. 
Pairing of the dominating and alternative narrative is of key importance in the narrative therapy.

Alternative narratives don't disappear. They settle in subconscious and people happen to return to them as resource which hasn't been properly used before. For example, both people's stories and world literature are rich with narratives about premature decisions following some dominant personalities or submitting to ideological brainwash, or due to overwhelming passions, etc. A person may think he or she does the right thing at the moment, whereas later he agrees it was mistake. Therapist meets the client in crisis situation when alternative narrative surfaces or, vice versa, the dominating one goes to the bottom - in any case the client agrees that his behavior could be determined by fully different and still very important motifs. Quite often this understanding is followed by confusion, it may take to reevaluation of the past, overlooking life essentials, etc.

\section{Externalization}

The dominating narrative shows tendency to rule over others, to push them into periphery, asks them to submit or embrace, creating somewhat despotic hierarchy. The dominating narrative fully pushes out other potential scenarios for action and people make decisions following the instant impulse. Narrative therapists recommend to "personify" the dominating narrative, to endow it with characteristics of the living, powerful, dominating and encompassing organism.

The core meaning of "externalization" is to "bring outside" and it has principal meaning in the NT. The term is known also within the context of Freudian depths psychology - externalization is a defense mechanism coming from subconscious when an individual project his or her inner characteristics on objects outside, especially on people (e.g., reject his own responsibility or guilt in a search for scapegoat) (Sandler, 1988). In the narrative therapy it helps to illustrate the key thesis of the method, namely, "the problem is not a client, the problem is a problem".

Externalization is necessary in order to escape the destructive conviction of the client and to secure against his neurosis and to accede to normal functioning consciousness. Externalization foresees break of the tie between the erroneous narrative and a person. By this the identity of a person is separated from problems he or she is stuck in.

Externalization refocuses attention from the client on to the erroneous narrative since narrative and not the client has entered crisis. Looking from the psychology perspective relocation of the focus helps to escape self-condemnation (e.g. "I was wrong, therefore I am stupid") and invites to analyze relationships with other narratives and reminds that "wrong" is narrative, a problem, rather than a person who accepts it. 
Externalization is needed also because it helps to see the situation from outside - it differs from the classical Freudian understanding. By use of externalization the NT urges client to make objective analysis of the narrative he is stick to, teaches evaluation of both strengths and weaknesses of it, and balance them. It helps to construct the new narrative and shape the chosen identity. My conclusion is that complete objectivity is not possible because the client is "inside" the situation, consequently he is emotionally stressed, therefore subjectivity is not avoided.

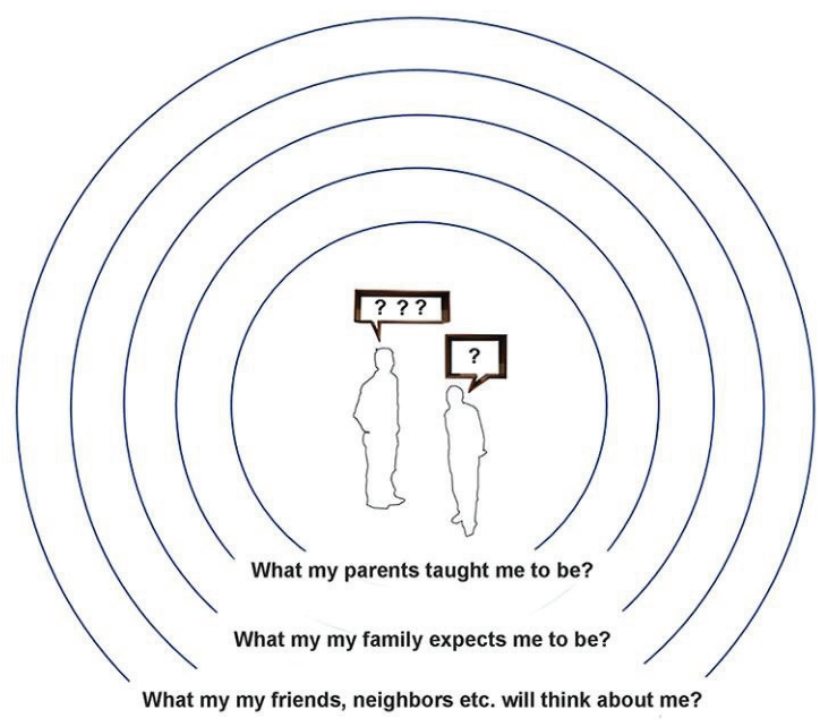

What the state ideology and control system wants me to be?

Fig. 1. Surrounding narratives force to answer few questions immediately at expense of "identity".

Source: author.

\section{Identity}

Although "identity" doesn't belong solely to the NT realm, however, one should deal with it in the process of sketching out the its tasks and goals. It is both essential and controversial term, partially due to search for "my identity" as a fashion search for "me", "myself", "my identity" is a call heard from diverse practitioners. One may say that search for "identity" has become a commercial undertaking.

What is the NT attitude to this term? The author suggests that any term is to be identified only within a certain metasystem, i.e., as set against certain criteria, 
however, narrative therapy distrusts anything in man what comes from "outside" by saying it is "imposed". At the same time NT rejects determination "being-by-itself" or "true self" and speaks mainly about social identity which could be changed up to a personal choice (White, 2007, 139).

"Personal identity as social" is criticized as a weakness of NT. Narrative therapy sides with social constructionism and rejects the idea of "absolute truth" since only socially sanctioned opinions are available. This perspective has been criticized particularly because then the client and his ego is lifted above the dominating cultural paradigms (Minuchin, 1998, p. 397-403; Doan, 1998, p. 379-385).

Also, NT practitioners emphasize that the client is a resource for himself who "knows" the content of the alternative narrative, consequently, the client is the best expert of his life. Therefore, the task of NT is to release, to open up and to put into light the potential of the alternative narrative or to point at its existence and rights to live out. On the other hand, the therapist may be looked upon as co-author in the process of becoming and maturing of the alternative narrative (Brown, AugustaScott, 2007, p. 24).

Also, critics point at the therapist's leadership role and his recommendations as the highest authority for a client, consequently, the therapist's voice becomes self-legitimising (Doan, 1998, 384). It means that stories entrusted are not adressed to any other higher authority or experts for proof of their authenticity or validity. Consequently, the quest for identity is endangered by imposing narrative authorized by the therapist.

Narrative therapy suffers criticism from family therapists because an individual narrative is lifted above the family (Carmel et al., 2013, p. 125). Minuchin says that NT rejects family and puts an emphasis on individual psychology (Minuchin, 1998, p. 403).

Our concept stems from analysis of those aspects from the caritative social work perspective. Identity in the context of the caritative social work is an operational part of the method. This conceptual thesis originited at Latvian Christian academy. Identity can be activated by use of NT and amortization of the NT weak points is possible. Identity is an ontological given, to put it in the Biblical phrase, it is "image and likeness of God" in His creature (Gen. 1: 26). This thesis is supported and taken up by Patristic anthropology (Eastern Church Fathers, 2nd-7th cent.). To put it simple, identity is foundation on which his or her understanding of values is based - as both given (image) and within a reach and to be achieved (likeness). Patristics teach the way how to master own the identity (to use pure theological term, to achieve salvation), and also Narrative therapy offers recommendations how to get closer to identity. In the language of Patristics it is called "God-likeness" (theo- 
sis in Greek), which is a process with no end in the created world, although this is more positive than negative due to the Divine energies made active in the process of deficiation. Narrative therapy could be used in the caritative social work for correction of the narrative choice (I am referring to the above mentioned relocation of the author). However, human identity is not a mystical or purely religious term since it embraces diverse social dimensions (e.g., responsibility and contexts of the system) (Иларион, митр., 2013).

\section{Implementation of the method}

Narrative therapy is interactive and always aimed at collaboration. Therapist seeks to understand how the unfolding conversation meets clients' expectations and needs. He may ask: "How do you see the direction of the conversation?" "Should we elaborate [this] or you perhaps would like to speak about [that]?"

Therapist doesn't teach how to live, his task is to direct and aim with questions, perhaps inconspicuous, towards the somewhere existing alternative narrative. After all the final decision must be made by the client himself. By looking into his own past the client observes as it were from outside. But how it is with the present moment and the necessity to make a step from here into the unknown, unfamiliar future? This is where the question of identity comes into picture, because the decision should be based on it.

For the narrative therapy to happen several logical steps should be made:

1. Listening to what client says. In his monologue the main conflict between the dominating and alternative narrative is revealed. However, from the beginning it may sound as a mixture of causes and consequences, elements of unfolding plot, the client's emotional attitude to events and facts described (e.g. anger, mockery, scorn all of them are rather expressive and outspoken which are easy to recognize from the first sight),

2. Therapist listens and marks the so-called critical points (unique outcomes, a term a Irvin Goffmann-Goffmann, Fine, Manning, 2003, p. 55), off-set from the dominating narrative pointing to some doubts and insecurity. As we have already said the alternative narrative is known to the client and he doesn't need a recipe from outside. The socalled critical points are tint fragments, elements of the alternative. To put it otherwise - critical points are pieces of information not envisaged by the dominating narrative, and they don't fit into its logics. In this context the therapist counts on information untouched by the dominating 
narrative, on still living - although almost forgotten - events. Perhaps therapist should encourage to revive events and choices which could help to build and strengthen the alternative.

3. The task of the therapist is to tie critical points into a more or less harmonized whole. Critical points are units of a system, the visible part of an iceberg, whereas links between them are hidden or lost, or undeveloped. In order to make sure that these nodles are identified correctly and the system is grasped, therapist repeatedly asks questions for precision.

4. At the same time questions are asked and answers are heard in order to reduce the impact of the therapist's subjective assumptions, on the other hand - they strengthen client's potential to identify his own alternative narrative.

5. Externalization is necessary for analysis, reevaluation and finally to change client's attitude towards the mistakable narrative. It may sound like invitation: "Do you see where such narrative has taken you?" In this way the client is relocated: not that he is in the center of the crisis, but rather he is invited as an expert capable to change the situation from within. This is the above-mentioned relocation and reauthoring in the NT, and the first step towards re-storying.

6. Involvement of other participants - by theory they are welcomed to support and to encourage the client. Their involvement is possible also in their physical absence by referring to important people in the clients' career who have noticed and valued his resources and potentials. After all no one is a "single warrior" and everyone needs support, especially in the crisis situation when the former narrative is out of meaning. These witnesses may be friends, colleagues, etc. Also their presence is important because it helps to avoid subjective constructions if the therapist shows off unwanted impact on the therapy process.

\section{Conclusions}

1. Narrative therapy is useful in work with social work clients when personality issues come in front; thus the concept of caritative social work is briefly introduced in the article.

2. The specific use of the narrative in therapy in social work requires conscious search for causes of the crisis in the clients' life and is 
made of causes-and-consequences presented in a story". The task of the therapy is to change the way the client sees his / her problems.

3. Several narratives coexist in the clients' presentation, and behind the dominating one there is also an alternative. The therapy process seeks to recognize the alternative potential for further enrichment.

4. The key of the Narrative therapy is to separate the client from his problems (externalization). The therapist invites to view the problem rather than personality, to analyze its weaknesses and strengths.

5. The method requires activity of the client - he /she is not put in the receiving end of the process, rather the client makes his / her decisions, and the task of the therapist is to lead the client towards this goal.

Few questions for discussion

1. What is the role personality issues besides social circumstances in the clients' crisis situation?

2. What is the difference between mere "life story" and "narrative" for the Narrative therapy purposes?

3. Please describe your typical social work clients, their will to take part in solution of their life situation? Are they ready to change their perspective?

4. What is the role of the therapists' task?

5. What are limits of the therapists' involvement in the Narrative therapy process?

\section{Literature}

Brown, C., Augusta-Scott, T., eds. (2007). Narrative Therapy. London: SAGE Publ.

Carey, M., Russell, S. (2003). Re-Authoring: Some answers to commonly asked questions compiled by Maggie Carey \& Shona Russell. The International Journal of Narrative Therapy and Community Work, No. 3.

Carmel, F., Stagoll, B., Larner, G., et al. (2013). Dialogues of Diversity in Therapy: A Virtual Symposium. Available at: https://onlinelibrary.wiley.com/doi/abs/10.1002/j.1467-8438.2000.tb00431.x

Doan, R. E. (1998). The King is Dead: Long Live the King: Narrative Therapy and Practicing What We Preach. Family Process, No. 37(3).

Epston, D., White, M. (1990). Story, knowledge, power. Narrative means to therapeutic ends. NY: Norton.

Freedman, J., Combs, G. (1996). Shifting paradigms: From systems to stories. Narrative therapy: The social construction of preferred realities. NY: Norton.

Goffmann, E., Fine G. A., Manning, P. (2003) The Blackwell Companion to Major Contemporary Social Theorists. Blackwell Publ.

Kahneman, D.,Tversky, A., eds. (2000). Choices, values, and frames. NY; Cambridge, UK: Russell Sage Found.; Cambridge Univ. Press.

Minuchin, S. (1998). Where is the Family in Narrative Family Therapy? Journal of Marital \& Family Therapy, No. 24(4). 


\section{Guntis Dišlers}

Sandler, J. (1988). Title Projection, identification, projective identification. Great Britain: H. Karnac Books.

Triantaphyllou, E. (2000). Multi-criteria decision making methods: a comparative study. Applied optimization. Netherlands, Dordrecht: Kluwer Academic Publ.

White, M. (1997). The culture of professional disciplines. Narratives of therapists' lives. Adelaide: Dulwich Centre Publ.

White, M. (2007). Maps of Narrative Practice. NY: Norton.

White, M., Epston, D. (1990). Narrative means to therapeutic ends. NY: Norton.

Иларион, митр. (2013). Семья, христианство, общество: православный взгляд. Доклад на конф. "Православные и католики вместе в защиту семьи". Available at: http://www.patriarchia.ru/db/ text/3365819.html [Ilarion Metropolitan. Family, Christianity, Society: Orthodox Perspective. Presentation at the Conference "Orthodoxes and Catholics together to support Family".] 